\title{
Measuring compliance of conducting an occupational health risk assessment in the occupational health nurse's practice
}

\begin{abstract}
Authors:
Nicolene de Jager ${ }^{1}$

Sonya Beukes ${ }^{1}$

Anna G.W. Nolte ${ }^{1}$

Affiliations:

${ }^{1}$ Department of Nursing, University of Johannesburg, South Africa

\section{Correspondence to:}

Anna Nolte

Email:

agwnolte@uj.ac.za

Postal address:

PO Box 524, Auckland Park

2006, South Africa

Dates:

Received: 10 Jan. 2012

Accepted: 16 Sept. 2013

Published: 29 Sept. 2014

How to cite this article: De Jager, N., Beukes, S. \& Nolte, A.G.W., 2014,

'Measuring compliance of conducting an occupational health risk assessment in the occupational health nurse's practice', Health SA Gesondheid 19(1), Art. \#647, 11 pages. $h t t p: / / d x . d o i$. org/10.4102/hsag.v19i1.647
\end{abstract}

\section{Copyright:}

(C) 2014. The Authors.

Licensee: AOSIS OpenJournals. This work

is licensed under the

Creative Commons

Attribution License.
Read online:

口ida Scan this QR code with your smart phone or mobile device to read online.

\begin{abstract}
Occupational health nurses (OHNs) are qualified registered nurses with a postgraduate qualification in occupational health nursing. An important activity of OHNs is to identify and assess health risks in the workplace. Health risk assessments (HRAs) are conducted by OHNs to determine all the occupational health stressors, for example noise, vibration and chemical substances. The authors conducted legal compliance occupational health audits and observed that $85 \%(n=23)$ of OHNs in different settings conduct HRAs only to a limited extent. The following objective was formulated for the study: To explore and describe the extent to which OHNs conduct HRAs as it is a legal requirement for compliance; and the possible reasons for not adhering to the regulation and conduct them only to a limited extent. A quantitative, descriptive design was used in this study. A sampling frame was developed from a list of all the members of the South African Society of Occupational Health Nursing Practitioners (SASOHN) in Gauteng. From the target population of OHNs in Gauteng, a systematic cluster sampling method was used. A self-developed questionnaire was distributed by mail and e-mail, and authors sent respondents reminders. The authors ensured that validity, reliability and ethical standards were adhered to. The findings revealed that $\mathrm{OHNs}$ are mature, experienced, predominately female practitioners who operate on behalf of a disproportionately large number of workers. Four factors influencing these nurses in conducting an HRA to a limited extent were identified: competence, ignorance about the role of the OHN, workload and attitude.
\end{abstract}

Beroepsgesondheidverpleegkundiges (BGV's) is gekwalifiseerde geregistreerde verpleegkundiges met 'n nagraadse kwalifikasie in beroepsgesondheidsverpleging wat basiese gesondheidsorg in die beroepsgesondheidsprogram lewer. 'n Belangrike aktiwiteit van die BGV is om alle gesondheidsrisiko's in die werksplek te identifiseer en te assesseer. Die BGV doen ook 'n gesondheidsrisiko-analise (GRA) om stressors soos geraas en vibrasie te identifiseer. Die navorsers het met besoeke aan verskillende fabrieke bevind dat $85 \%$ $(n=23)$ van BGV's GRA's net in 'n sekere mate doen, alhoewel 'n GRA wetlik vereis word. Die volgende doelwit is vir die studie geformuleer: Om te ondersoek en te beskryf in watter mate BGV's GRA's uitvoer, en om die moontlike redes vir die nie-nakoming van die regulasie te ondersoek. 'n Kwantitatiewe, beskrywende navorsingsmetode is gebruik. 'n Sistematiese groepsteekmetode is gebruik om 'n steekproefraamwerk uit 'n lys van die SASOHN-lede in Gauteng saam te stel. 'n Selfontwikkelde vraelys is aan respondente gestuur. Die navorsers het geldigheid, betroubaarheid asook etiese standaarde gehandhaaf. Daar is bevind dat BGV's ouer, hoofsaaklik vroulike praktisyns met bo-gemiddelde ondervinding is wat vir'n groot getal werkers verantwoordelik is. Vier faktore is geïdentifiseer wat BGV's beïnvloed om GRA's net in 'n sekere mate uit te voer, naamlik bevoegdheid, onduidelikheid betreffende die rol van die $\mathrm{BGV}$, werkslading en houding.

\section{Introduction}

Occupational health nursing as a discipline focuses on addressing the healthcare needs of workers in the workplace. The primary focus of occupational health nursing is to promote health and minimise risk of workers exposed to occupational health stressors within a work environment. Occupational health nursing dates back to as far as 1710. During the times when medicine was dominated by traditions of ancient and mediaeval pathology, Bernardo Ramazzini (1633-1714), recognised as the father of occupational health (Waldon 1989), generated a totally new paradigm concerning the impact of work and social conditions on workers' health. In particular, he recognised occupational hazards, such as dangerous substances and un-ergonomic working postures and movements as causes of diseases (Carnevale, Mendini \& Moriani 2009).

Occupational health nursing has evolved and expanded into a unique nursing speciality. From 1966 to 1969, a nursing subcommittee of the Scientific Committee on Occupational Health Nursing conducted a study in 57 countries regarding the contribution of the nurse to the 
health of the worker'. It was found that over the previous 30 years occupational health nurses (OHNs) had moved from tertiary or injury care in company dispensaries under the supervision of the physician to independently providing more preventive healthcare for workers, such as education and worker training, hazard evaluation, medical surveillance and occupational health surveys. OHNs had also assumed responsibility for case management, where occupational health problems were investigated, and ergonomic evaluations and interventions to help workers maintain the correct body posture when performing their work. It was also found that OHNs were employed in a wide range of private industrial employment sectors where they provide health care services. They had more support in the form of professional organisations and recognised the value of collaboration and sharing of information via scientific committees and professional presentations by conducting research. It was also found that national legislation and consultation with OHNs in the legislative process are vital. Therefore the OHNs can access a variety of educational offerings to advance their careers and build their expertise. Today OHNs plan, manage, direct, control and evaluate both the business healthcare and the care of the world's workforce (Burgel, Camp \& Lepping 2005).

Identifying health risks in the workplace is the most important function of the $\mathrm{OHN}$ and forms the basis of the occupational health programme. By undertaking health protection measures, such as education on the use of the correct personal protective equipment for example hearing protection in the work environment, the risk of disease (in this case, hearing loss) will be eliminated or reduced in order to prevent the development of an illness or injury.

Walk-throughs are health protection activities undertaken by the $\mathrm{OHN}$ in practice to identify work hazards whilst workers are performing their respective work tasks (Rogers 2003). By conducting a walk-through, the $\mathrm{OHN}$ becomes familiar with the work environment, production processes and methods, and equipment handling and work practices (Rogers 2003). When the OHN conducts a health risk assessment (HRA) in the workplace, potential hazards and risks to the workers are identified as per the Hazardous Chemical Substances Regulation 5(1) of 1995 of the Occupational Health and Safety Act 83 of 1993 (OHSA) (Department of Labour of South Africa 1993c).

\section{Problem statement}

The HRA should be conducted by the OHN in order to determine all the hazards and stressors which may affect workers' health and working efficiency. Hazards which workers may be exposed to include hazardous chemicals, vibration, insufficient lighting, noise exposure and thermal exposure. The Hazardous Chemical Substances Regulation 5(1) of 1995 of the OHSA stipulates that an employer or selfemployed person 'shall, after consultation with the relevant health and safety representative or relevant health and safety committee, cause an immediate assessment and thereafter at intervals not exceeding two years, to determine if any worker may be exposed by any route of intake' (Department of Labour of South Africa 1993b).

The first author is employed by an international company who own several operations, each of which has an occupational health service. She was instructed by her employer to conduct legal audits over a period of two years as it was the company's goal to be compliant by the end of that period. The findings of the audits revealed that $85 \%(n=23)$ of the OHNs employed by the company only conducted HRAs to a limited extent and is not legally compliant as per the Hazardous Chemical Substances Regulation 5(1) of 1995 of the OHSA (Department of Labour of South Africa 1993b). She also observed that $99 \%(n=6)$ of the OHNs did not fully comply with the Hazardous Chemical Substances Regulation which stipulates that OHNs must conduct an HRA biannually. She questioned two occupational health specialists in private practice and audited her own occupational health clinic for legal compliance. It was established that they had all come to the same conclusion, namely that OHNs conduct HRAs to a limited extent only. It was also established that the managers of the OHNs, that is health and safety managerswho have little or no knowledge of health, conduct the HRA in the workplace rather than the nurses themselves. The following questions were raised:

- To what extent do OHNs employed in industry conduct HRAs in compliance with the Hazardous Chemical Substances Regulation?

- What are the possible reasons for not adhering to the regulation and conducting them only to a limited extent?

- What can be done to assist OHNs in conducting HRAs according to regulations?

\section{Research purpose and objective of the study}

The purpose and objectives of this study were to explore and describe the extent to which OHNs conduct HRAs, as it is a legal requirement for compliance, and to explore the possible reasons for not adhering to regulations and conducting them to a limited extent only.

\section{Definitions of central concepts Occupational health}

Occupational health is primarily a prevention-oriented activity, involved in risk assessment, risk management and proactive strategies aimed at promoting the health of the working population. Occupational health is the specialist branch of healthcare that is concerned with the effects of health and the ability to work and the adverse effects of work on health (Zungu 2007).

\section{A health risk assessment}

A health risk assessment (HRA) usually involves identifying the hazards present in any working environment or arising from commercial and work-related activities, and evaluating 
the extent of the risks involved, taking into account existing precautions and their effectiveness. HRA is the process of evaluating the risks to health arising from hazards at the workplace (Guild et al. 2001), identified by conducting a walk-through. The HRA is documented in a procedure and is used as a guide for the OHN.

\section{Occupational health nurse}

The occupational health nurse $(\mathrm{OHN})$ is a registered nurse who practises in accordance with relevant nursing legislation, codes of ethics, practice standards, workplace policies and procedures, and other legislation applicable to the workplace. The OHN holds a qualification in occupational health recognised as such by the South African Nursing Council (SANC) as referred to in the Nursing Act 50 of 1978 as per the OHSA (Department of Labour of South Africa 1993c).

\section{Extent}

Extent can be defined, according to the Oxford Dictionaries (2013), as the particular degree to which something is or is believed to be the case. The HRA process is conducted to a limited extent if the health hazards are partially identified, if the HRA is not conducted bi-annually, and if there is no legal compliance with the Hazardous Chemical Substances Regulation.

\section{Research design and methods Research design}

A quantitative descriptive research design was used in this study. Descriptive research provides an accurate portrayal of characteristics of the occupational health group (Alstone \& Bowles 2003). Descriptive studies are usually conducted when little is known about the phenomenon. Using a questionnaire as the instrument enabled the occupational health field to be described and knowledge on it to be acquired (Burns \& Grove 2006). Therefore a descriptive design was used to gather specific, formal information that described the extent to which HRAs were conducted.

\section{Research method}

The research method comprised two phases. This article will only focus on phase 1 , which entailed exploring and describing the extent to which OHNs conduct HRAs and the reasons for not conducting such assessments. Phase 2 focused on the development of guidelines and will not be discussed in this article.

\section{Population and sample}

The target population consisted of 1054 OHNs providing occupational health services in an occupational health setting in Gauteng, South Africa. The target population was divided into clusters representing the four regions in Gauteng as they were accessible to the researchers. All OHNs in these regions are registered with the SANC and are on the database of the South African Society of Occupational Health Nursing
Practitioners (SASOHN). In 2011, the database had the following number of members per region: Gauteng Central $n=499$, Vaal $n=149$, West Rand $n=133$ and Pretoria $n=273$ (SASOHN 2011).

The researchers used a systematic cluster sampling method (Burns \& Grove 2006). As the population was spread across South Africa, it was decided to only use the regions that were accessible to the researchers, namely Gauteng Central, Vaal, West Rand and Pretoria. A sampling frame was developed from a list of all SASOHN members in Gauteng $(n=1054)$. All respondents had to have a qualification in occupational health, recognised as such by the SANC as referred to in the Nursing Act 50 of 1978 as per the OHSA (Department of Labour of South Africa 1993c). A systematic sample of 200 respondents was drawn by selecting every fifth name from each of the four regional SASOHN membership lists as the database was accessible and the respondents available. This was done by dividing the population size $(n=1054)$ by the sample size $(n=200) ;(1054 \div 200=5)$ therefore, every fifth responded was selected. Only 156 out of the 200 respondents completed the questionnaire.

\section{Data collection instrument}

A questionnaire was developed after a literature study was done to explore and describe the extent to which OHNs conduct HRAs. The questionnaire consisted of three sections, namely A, B and C. Section A containedquestions to obtain demographic data and will not be discussed in this article, Section B contained questions that covered information on the extent to which OHNs conducted HRAs in the factory where they were employed, and Section C contained questions that covered possible reasons for OHNs not conducting HRAs. The questionnaires were self-administered. Items were rated by means of closed, open-ended and Likert scale questions in Sections A and B of the questionnaire, and by only a Likert scale in Section C (Cormack 1996; Markusic 2009). After designing the questionnaire the researchers had experts in the field of occupational health nursing, experts in research methodology and statisticians review the questionnaire to ensure content and face validity (Burns \& Grove 2006). A pilot study was conducted as a pre-test to test the relevance and consistency of the questionnaire. OHNs employed at the same company asthe researchersparticipated in the pilot study. The results of the pilot study were not used in the current study as these OHNs were not in the Gauteng area.

In September 2010 the questionnaire was mailedto all potential respondents who had been systematically selected from the SASOHN database. Total confidentiality was ensured as no details of the respondents were included in the study or revealed to anyone. All information was stored in a safe place and no one other than the researchers had access to it. A covering letter, together with an envelope and a stamp for return mail, accompanied the questionnaire to explain the goal and objectives of the research project. The OHNs had monthly meetings in the regions, and the researchers used this forum to motivate and explain to the members how to 
the complete the questionnaire (Burns \& Grove 2006). The researchers sent continuous e-mails and reminders, and conducted motivation sessions to increase the response rate.

\section{Data analysis}

The data were captured and coded, transforming data into numerical symbols, which were computerised and included in the statistical data. A statistician analysed the data using Statistical Package for Social Sciences 18.0 (SPSS) (Burns \& Grove 2006). All coded data were entered on a spreadsheet, with a series of rows and columns. Each row and column was labelled so individual squares could be cross-referenced. If the respondent chose not to answer a particular question, a specific code was allocated to the missing data (Cormack 1996; O'Neil 2009). The open-ended questions were coded by the researchers (Burns \& Grove 2006).

A factor analysis using the Kaiser-Meyer-Olkin measure of sampling adequacy (KMO) confirmed the accuracy and reliability of the data. The selection of factors for the factor analysis was determined by using eigenvalues. Cronbach's alpha coefficient of reliability was used to measure the consistency of the factors in the questionnaire (see Table 1) (Pallant 2007; Weiers 2008).

After the analysis was completed, the results were summarised, organised, evaluated, interpreted and communicated by the researchers in a presentation to SASOHN members (Burns \& Grove 2006).

\section{Results}

Only 156 of the 200 questionnaires were completed. Based on the data analysis, findings were discussed in the context of existing literature. The following interpretation of the results of the questionnaires was made.

\section{The extent to which the occupational health nurses conduct health risk assessments}

It is a legal requirement of OHSA that OHNs conduct HRAs in the workplace. More than two-thirds $(67.5 \%, n=104)$ of the respondents reported that they conducted an HRA in their workplace, whilst almost a third $(32.5 \%, n=50)$ did not conduct an HRA. Two respondents $(n=2)$ did not answer this question.

A seven-point Likert scale was used, with the options never, rarely, seldom, sometimes, frequently, usually and always, to assess the frequency of conducting a walk-through when preparing for an HRA (see Figure 1). A total of $25.7 \%(n=36)$ of the respondents conducted a walk-through only sometimes or frequently, and $10 \%(n=14)$ usually conducted a walkthrough prior to an HRA. About a fifth of the respondents

TABLE 1: Cronbach's alpha coefficient of reliability.

\begin{tabular}{lll}
\hline Factor & Cronbach's alpha & $N$ of items \\
\hline 1 & .925 & 5 \\
2 & .880 & 8 \\
3 & .905 & 4 \\
4 & .832 & 3 \\
\hline
\end{tabular}

$(21.4 \%, n=30)$ indicated that they always conducted a walkthrough prior to an HRA. Camp and Tanberg (1985) and Rogers (2003) emphasise the importance of a walk-through prior to an HRA as a means of identifying health hazards.

As a walk-through is conducted to identify hazards in the workplace, it is an important step in conducting an HRA. However, the OHNs surveyed did not regularly conduct walk-throughs in the workplace by themselves (see Figure 2). Only 13.8\% $(n=32)$ of the OHNs did not have any accompaniment when conducting an HRA. Some 27.2\% $(n=63)$ of the respondents indicated that the occupational health medical practitioner accompanied them, whilst

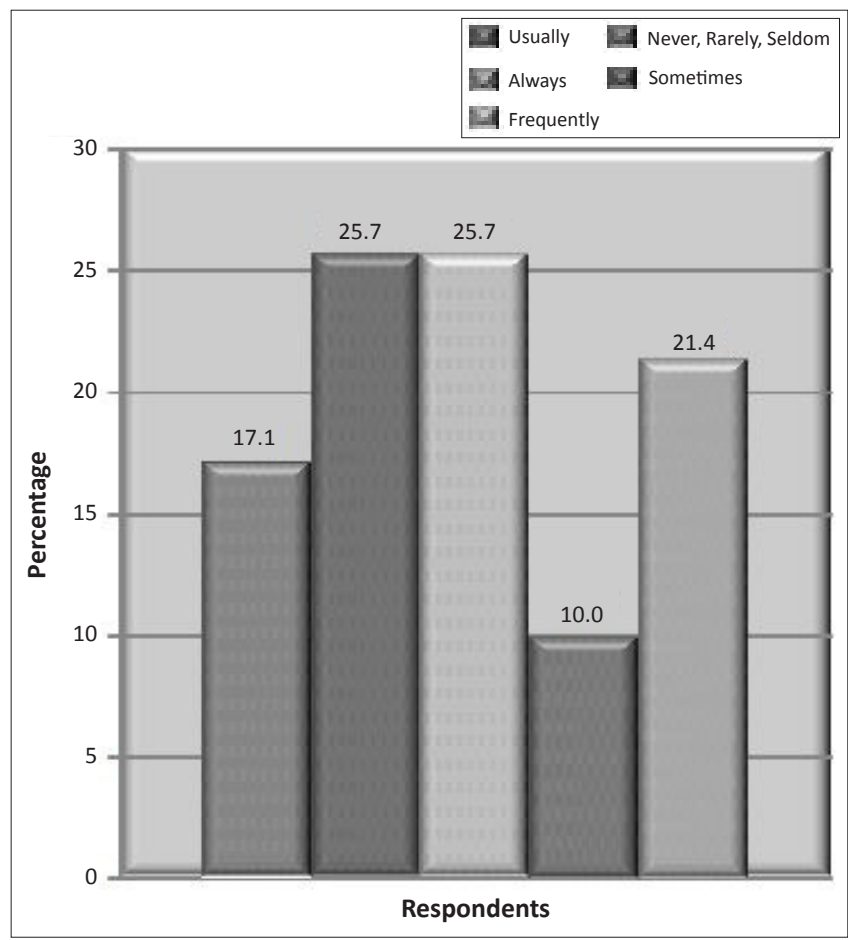

HRA, health risk assessments.

FIGURE 1: Conducting a walk-through prior to a health risk assessments $(n=140)$.

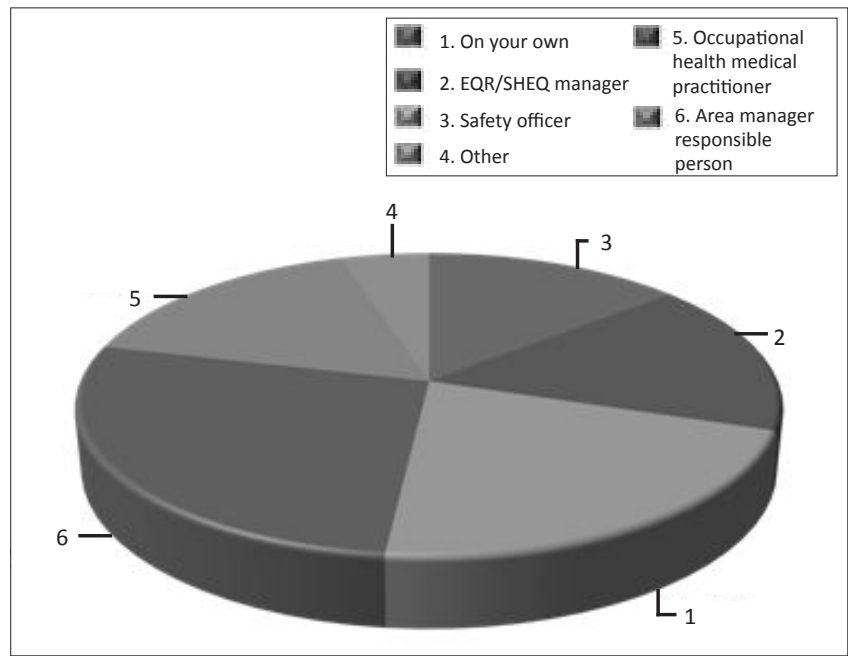

FIGURE 2: Individuals accompanying occupational health nurses when conducting a walk-through $(n=132)$. 
$4.7 \%(n=11)$ of the respondents said that 'other' people accompanied them.

According to the Occupational Health and Safety Management Systems of South Africa (2005), all processes, such as conducting an HRA, must be documented in a policy or procedure. The answers to the questionnaire revealed that only $72.1 \%(n=98)$ of the respondents had a written policy or procedure on how to conduct an HRA, whilst $27.9 \%$ $(n=38)$ did not.

In terms of Circular Instruction 180 regarding compensation for work-related upper limb disorders, an HRA must be conducted by the OHN to identify work-related injuries where the relation between the person, the workplace and the environment is enhanced (Department of Labour of South Africa 2003). More than half of the respondents (87.9\%, $n=124$ ) indicated that they conducted ergonomic surveys.

The OHSA is specific in the Environmental Regulation for Workplaces regarding the employer's legal obligation to ensure that the workplace is provided with the correct illumination (Department of Labour of South Africa 1993c). However, only half of the respondents $(50.4 \%, n=71)$ reported that they conducted a lighting survey.

The Hazardous Biological Agents Regulation (Department of Labour of South Africa 1993a) provides that the employer must conduct an HRA on hazardous biological agents every two years. All agents such as bacteria, viruses and fungi must be identified by the OHN. This study indicated that $42.4 \%(n=59)$ of the respondents conducted surveys on bacteria, and $27.3 \%(n=38)$ conducted surveys on viruses. Only $28.1 \%(n=39)$ of the respondents conducted surveys on fungi. It is imported to note that OHNs are exposed to hepatitis, influenza, HIV and other agents. Workers are exposed to Escherichia coli, Taenia and many more, which can cause occupational illnesses at the workplace. The importance of assessing hazardous biological agents is highlighted in studies conducted by Singh (2010), where workers were diagnosed with airborne contact dermatitis caused by biological agents. Further studies conducted by Dikeledi and Singh (2010) identified health effects associated with exposure to hazardous biological agents and their constituents in the poultry farming environment. Poultry workers had an increased incidence of respiratory symptoms and a decline in lung function related to exposure to bacteria, fungi, viruses and mites (Dikeledi \& Singh 2010).

In this study, more than half $(55.4 \%, n=77)$ of the respondents conducted a psychological assessment on their workers. This is a requirement to ensure that workers are psychologically fit to conduct work at a workplace (Department of Labour of South Africa 2003). All workers working on heights and driving machinery must undergo psychological assessment as per the OHSA. If a worker is psychologically unfit, possible suicide attempts and injuries can be a costly burden to the employer.

Depending on the size of the factory, it should take more than two weeks to conduct a well-designed and documented HRA (ICMM 2009). It is evident that the OHNs surveyed spent adequate time conducting HRAs. A third of the respondents $(29.5 \%, n=33)$ indicated that they spent one month on conducting an HRA. Respondents taking two weeks to conduct an HRA constituted $23.2 \%(n=26)$. A total of $17.9 \%(n=20)$ spent one day and $7.1 \%(n=8)$ spent only one hour on conducting an HRA.

An HRA should be conducted bi-annually as per the Hazardous ChemicalSubstances Regulation(Department of Labour of South Africa 1993b). More than a quarter of the respondents $(29.8 \%, n=$ 39 ) indicated that they sometimes conducted an HRA, and 28.2\% $(n=37)$ reported that they conducted it frequently (see Figure 3$)$. The respondents who indicated that they always conducted an HRA constituted $13.7 \%(n=18)$. The researchers grouped the responses for never $(9.9 \%, n=13)$, rarely $(7.6 \%, n=10)$ and seldom $(6.1 \%, n=8)$ together, and it amounted to less than a quarter $(23.6 \%, n=31)$ of the respondents.

The HRA document is the foundation of the medical surveillance programme. AOHNA (2005) and Rogers (2003) state that after the OHN has conducted an HRA, data and findings are reviewed in order to initiate and implement the medical surveillance programme. A Likert scale with the options never, rarely, seldom, sometimes, frequently, usually and alwayswas used to determine if this was the case in this study. As indicated in Figure 4, 5.1\% $(n=7)$ of the respondents

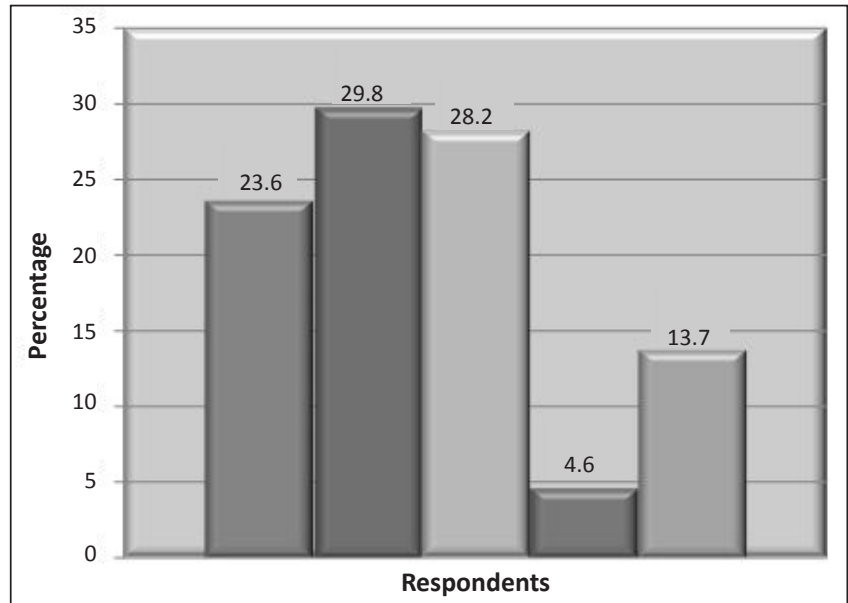

FIGURE 3: Frequency of conducting a health risk assessments $(n=131)$.

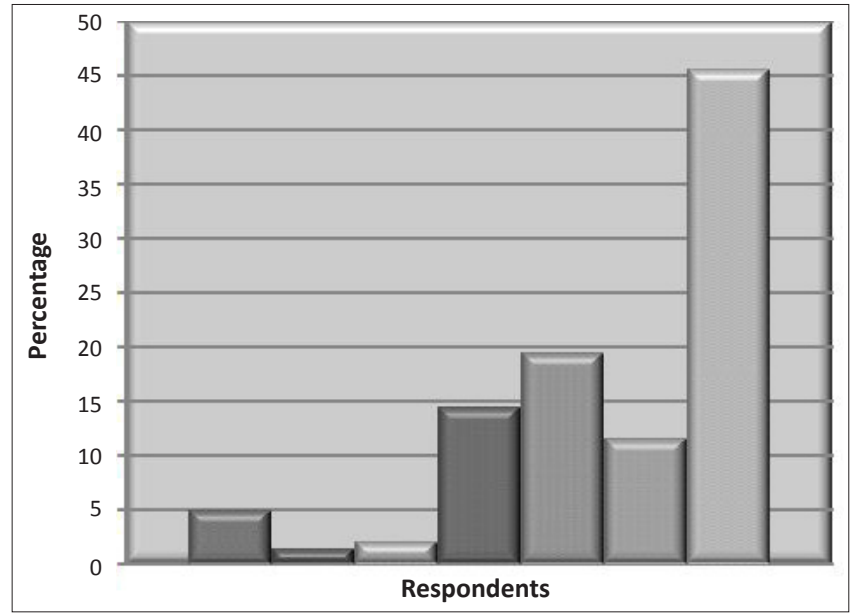

FIGURE 4: Using the health risk assessments document as the basis of the medical surveillance programme $(n=138)$. 
indicated that they never used the HRA document as the basis of their medical surveillance programme, $1.4 \%(n=2)$ did so rarely, $2.2 \%(n=3)$ seldom, $14.5 \%(n=20)$ sometimes, $19.6 \%(n=20)$ frequently, $11.6 \%(n=16)$ usually and $45.7 \%$ $(n=63)$ always.

According to the University of Waterloo (2007), the Ontario Health Promotion E-Bulletin (2008) and the University of Queensland (2010), it is both internationally and nationally accepted that medical surveillance will follow after an occupational HRA has been conducted. Although less than half of the respondents conducted an HRA as a basis for their medical surveillance programme, more than half conducted medical examinations after conducting an HRA.

It was found that not only OHNs and other medically trained staff interpreted the findings of the HRA, but also staff not medically trained (see Figure 5). OHNs are the experts in their field and should know what the adverse effects of hazards in the workplace are (Rogers 2003). Staff members who are not medically trained cannot decide what medical surveillance needs to be conducted on the workers in the workplace.

It is important that management are made aware of the health risks which workers are exposed to. Compensation and/or damages to ill or disabled workers or to the families of workers that are killed can escalate to enormous figures (Kritzinger 2009). A small percentage of respondents (6.9\%, $n=9$ ) never reported health hazards to management, $1.5 \%$ $(n=2)$ rarely and seldom reported to management and $12.3 \%$ $(n=16)$ only sometimes. Less than a quarter $(22.3 \%, n=29)$ reported their findings to management frequently, $14.6 \%$ $(n=19)$ did so usually and $40.8 \%(n=53)$ did so always.

As shown in Figure 6, 28.6\% $(n=2)$ of the respondents reported that management indicated that it is the OHN's job to conduct an HRA, $14.3 \%(n=1)$ felt that management was not interested in their input and $57.1 \%(n=4)$ reported that there were other reasons for not sharing the findings of the HRA with management but did not state what they were.

The OHNs surveyed were asked to indicate to what extent conducting an HRA was included in their performance appraisal. It was reported by $10.1 \%(n=13)$ of the respondents that their managers did not conduct an appraisal at all, whilst $4.7 \%(n=6)$ of the respondents stated that their managers decided what to include in their appraisal. Less than half $(45.7 \%, n=59)$ of the respondents indicated that conducting an HRA was included in their performance appraisal, whilst $36.4 \%(n=47)$ that that conducting an HRA was not included in their appraisal. Conducting an HRA was not expected of $1.6 \%(n=2)$ of the respondents.

\section{Possible reasons for the extent to which health risk assessments were conducted}

In Section $C$ of the questionnaire, 20 items were listed and explained, and the respondents were asked to indicate which of these aspects might influence the extent to which they conducted HRAs. A Likert scale with the optionsnever, rarely,

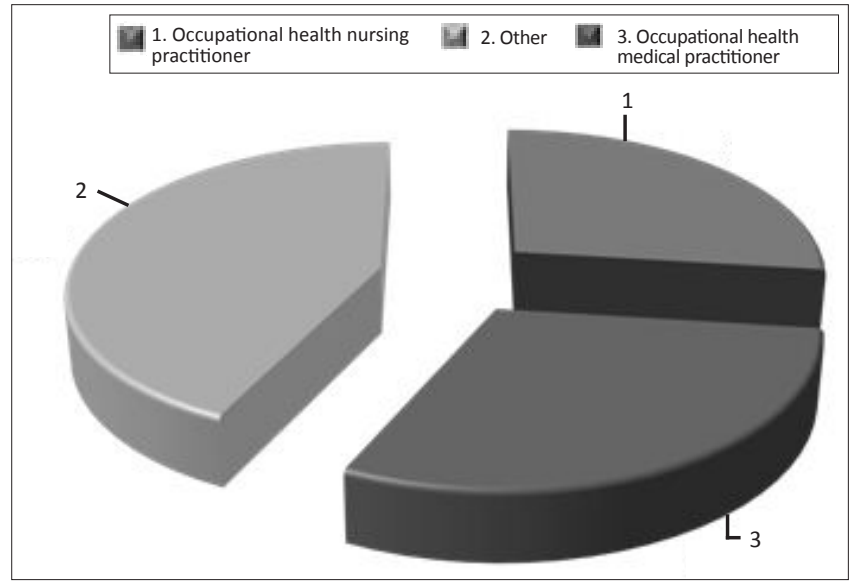

FIGURE 5: People analysing and interpreting findings of the health risk assessments $(n=134)$.

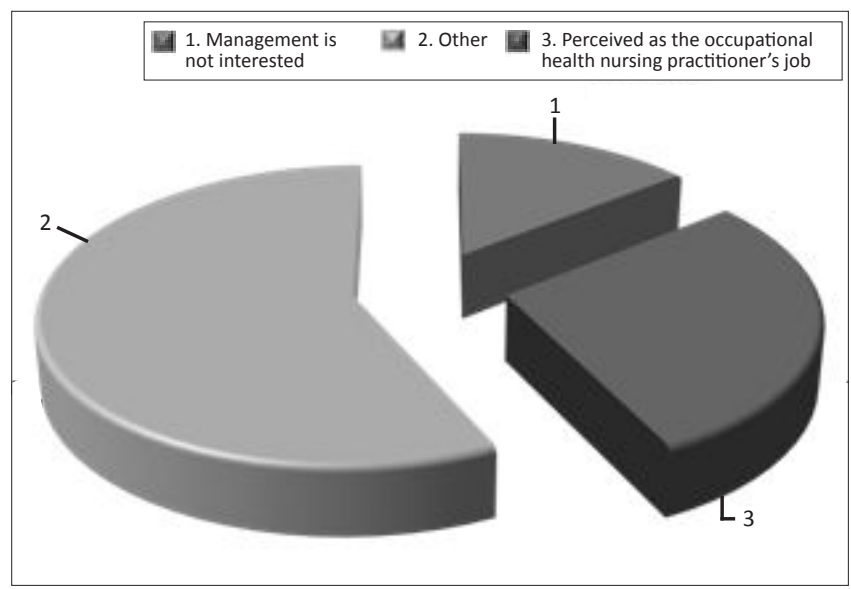

FIGURE 6: Reasons for not sharing findings with management $(n=7)$.

seldom, sometimes, frequently, usually and always was used (see Table 2). The researchers clustered and calculated the first three frequencies together and the last four frequencies together. The first three frequencies indicated a positive response and the last four a negative response. The following were the most important findings in Section C:

- Some $65.1 \%(n=75)$ respondents responded that they did not have enough time to conduct an HRA.

- About halfof the respondents $(51 \%, n=56)$ indicated that their time was occupied by leadership and/or management responsibilities.

- Whilst 35.5\% ( $n=39)$ respondents reported that they were clear about their tasks and goals as an $\mathrm{OHN}$, more than a quarter $(39.1 \%, n=43)$ of the respondents reported that their tasks and goals as an $\mathrm{OHN}$ were not clear.

- A total of $46.9 \%(n=53)$ of the respondents indicated that they lacked knowledge in conducting an HRA.

- Although more than half $(52.7 \%, n=59)$ of the respondents indicated that they did not lack experience in conducting an HRA, $47.3 \%(n=53)$ indicated that they lacked such experience.

- Whilst $60.3 \%(n=67)$ of the respondents indicated that they did not lack confidence in conducting an HRA, $39.6 \%(n=44)$ indicated that they did.

- The respondents said that the ratio of OHNs to workers was 1:900. Less than half of the respondents $(47.2 \%, n=52)$ 
felt that the ratio of OHN to workers was acceptable, whilst $52.7 \%(n=58)$ of the respondents felt that they were responsible for too many workers.

The 20 items were factor analysed using principal component analysis as it would be an indication of why the OHNs are not complying with legislation regarding conducting an HRA.

The KMO was used as statistical measure to help assess the factorability of the data in order to ensure that factor analysis was considered appropriate. According to Pallant (2007), the $\mathrm{KMO}$ index ranges from 0 to 1 , with 0.6 suggested as the minimum value for a good factor analysis. Field (2006) recommends accepting values greater than 0.5 as acceptable, between 0.5 and 0.7 as mediocre, between 0.7 and 0.8 as good and between 0.8 and 0.9 as excellent. In this study the $\mathrm{KMO}$ value was 0.861 , and factor analysis was therefore appropriate for this data.

Eigenvalues are the sum of the squared weights for each factor to determine how many factors will be included in the factor analysis. The number of factors to include is determined by the minimal amount of variance that must be explained

TABLE 2: Reasons for not conducting a health risk assessment.

\begin{tabular}{|c|c|c|c|c|c|c|c|c|}
\hline Reasons & Never & Rarely & Seldom & Sometimes & Frequently & Usually & Always & Variable \\
\hline $4.8 .1(n)$ & 74 & 18 & 4 & 9 & 2 & 3 & 3 & 4.8 .1 \\
\hline $\begin{array}{l}\text { Personality conflict with the occupational health } \\
\text { medical practitioner. }\end{array}$ & 65.5 & 15.9 & 3.5 & 8.0 & 1.8 & 2.7 & 2.7 & $\%$ \\
\hline 4.8 .2 & 23 & 10 & 4 & 39 & 11 & 17 & 12 & $n$ \\
\hline $\begin{array}{l}\text { Daily workload. I do not have enough time to conduct } \\
\text { an HRA. }\end{array}$ & 19.8 & 8.6 & 3.4 & 33.6 & 9.5 & 14.7 & 10.3 & $\%$ \\
\hline 4.8 .3 & 49 & 13 & 15 & 17 & 7 & 3 & 6 & $n$ \\
\hline $\begin{array}{l}\text { Discrimination in terms of your profession. Other } \\
\text { professionals believe that you are not capable of } \\
\text { conducting an HRA. }\end{array}$ & 44.5 & 11.8 & 13.6 & 15.5 & 6.4 & 2.7 & 5.5 & $\%$ \\
\hline 4.8 .4 & 24 & 13 & 17 & 31 & 10 & 9 & 6 & $n$ \\
\hline $\begin{array}{l}\text { Leadership and/or } \\
\text { management responsibilities are taking too much time in } \\
\text { a day. }\end{array}$ & 21.8 & 11.8 & 15.5 & 28.2 & 9.1 & 8.2 & 5.5 & $\%$ \\
\hline 4.8 .5 & 39 & 16 & 12 & 22 & 7 & 10 & 4 & $n$ \\
\hline Lack of clarity about tasks and goals as an OHN. & 35.5 & 14.5 & 10.9 & 20.0 & 6.4 & 9.1 & 3.6 & $\%$ \\
\hline 4.8 .6 & 45 & 15 & 6 & 20 & 11 & 6 & 7 & $n$ \\
\hline $\begin{array}{l}\text { Lack of reward. I feel that I do not get sufficient reward } \\
\text { for what I accomplish in a day. }\end{array}$ & 40.9 & 13.6 & 5.5 & 18.2 & 10.0 & 5.5 & 6.4 & $\%$ \\
\hline 4.8 .7 & 60 & 17 & 7 & 18 & 3 & 1 & 3 & $n$ \\
\hline $\begin{array}{l}\text { Possibility of future unemployment. The company is } \\
\text { not currently doing well financially. }\end{array}$ & 55.0 & 15.6 & 6.4 & 16.5 & 2.8 & 0.9 & 2.8 & $\%$ \\
\hline 4.8 .8 & 69 & 17 & 8 & 10 & 2 & 0 & 1 & $n$ \\
\hline Personal problems. & 64.5 & 15.9 & 7.5 & 9.3 & 1.9 & 0 & 0.9 & $\%$ \\
\hline Lack of skill in conducting an HRA. & 31.5 & 12.6 & 10.8 & 18.9 & 9.9 & 10.8 & 5.4 & $\%$ \\
\hline 4.8 .10 & 35 & 14 & 11 & 25 & 9 & 13 & 6 & $n$ \\
\hline Lack of knowledge in conducting an HRA. & 31.0 & 12.4 & 9.7 & 22.1 & 8.0 & 11.5 & 5.3 & $\%$ \\
\hline 4.8 .11 & 29 & 15 & 15 & 23 & 10 & 14 & 6 & $n$ \\
\hline Lack of experience in conducting an HRA. & 25.9 & 13.4 & 13.4 & 20.5 & 8.9 & 12.5 & 5.4 & $\%$ \\
\hline 4.8 .12 & 38 & 15 & 14 & 19 & 8 & 12 & 5 & $n$ \\
\hline Lack of confidence in conducting an HRA. & 34.2 & 13.5 & 12.6 & 17.1 & 7.2 & 10.8 & 4.5 & $\%$ \\
\hline 4.8 .13 & 60 & 23 & 13 & 9 & 2 & 1 & 4 & $n$ \\
\hline Conflict with your manager. & 53.6 & 20.5 & 11.6 & 8.0 & 1.8 & 0.9 & 3.6 & $\%$ \\
\hline 4.8 .14 & 22 & 7 & 9 & 33 & 17 & 15 & 7 & $n$ \\
\hline Time management. I have too many tasks to do in the day. & 20.0 & 6.4 & 8.2 & 30.0 & 15.5 & 13.6 & 6.4 & $\%$ \\
\hline 4.8 .15 & 27 & 10 & 15 & 19 & 16 & 12 & 11 & $n$ \\
\hline Responsible for too many workers. & 24.5 & 9.1 & 13.6 & 17.3 & 14.5 & 10.9 & 10.0 & $\%$ \\
\hline I fail to prioritise all my tasks as an $\mathrm{OHN}$. & 37.0 & 24.1 & 14.8 & 16.7 & 3.7 & 1.9 & 1.9 & $\%$ \\
\hline 4.8.17 & 78 & 14 & 5 & 6 & 1 & 2 & 2 & $n$ \\
\hline I do not feel it is necessary to conduct an HRA. & 72.2 & 13.0 & 4.6 & 5.6 & 0.9 & 1.9 & 1.9 & $\%$ \\
\hline 4.8.18 & 79 & 9 & 5 & 10 & 1 & 1 & 1 & $n$ \\
\hline I am not interested in conducting an HRA. & 74.5 & 8.5 & 4.7 & 9.4 & 0.9 & 0.9 & 0.9 & $\%$ \\
\hline 4.8 .19 & 54 & 9 & 8 & 7 & 9 & 8 & 12 & $n$ \\
\hline I was not trained in conducting an HRA. & 50.5 & 8.4 & 7.5 & 6.5 & 8.4 & 7.5 & 11.2 & $\%$ \\
\hline 4.8 .20 & 58 & 18 & 6 & 14 & 6 & 3 & 4 & $n$ \\
\hline My input as an $\mathrm{OHN}$ is not valued. & 53.2 & 16.5 & 5.5 & 12.8 & 5.5 & 2.8 & 3.7 & $\%$ \\
\hline
\end{tabular}

HRA, health risk assessment; OHN, occupational health nurses. 
by the factor to add significant meaning (Burns \& Grove 2006). The approach followed by the researchers was to select factors that have an eigenvalue of 1.00 or above, as described by Burns and Grove (2006). The eigenvalues recorded were 9.132, 2.180, 1.875 and 1.495. These four components explained a total of $73.407 \%$ of the variance.

Cronbach's alpha is a coefficient of reliability or consistency. Cronbach's alpha test was computed to measure the internal consistencies of the factors used in the questionnaire. According to the Academic Technology Services (2002) at the University of California, Cronbach's alpha measures how well a set of items (or variables) measures a single one-dimensional latent construct. A reliability coefficient of 0.7 to 0.8 or higher is considered as acceptable (Field 2006; Academic Technology Services 2002). All four factors were above 0.8. The reliability score of above 0.8 for this study indicated and ensured a high degree of consistent and reliable results in repeated incidents.

Reliability was further tested by testing all 20 items on factors influencing HRA. In the second-order confirmatory factor analysis, the Cronbach's alpha was 0.934 .

As indicated in Table 3, the following factors were identified: competence of the OHN to conduct an HRA, ignorance of the role of the OHN by the managers of the OHNs regarding conducting an HRA, workload of the OHN to conduct an HRA and attitude of the OHN to conduct an HRA. It was confirmed that these factors are the reasons why the OHNs experience difficulty in conducting an HRA as per legal requirements.

\section{Ethical considerations Human rights of the respondents}

A self-administered questionnaire with a covering letter informing the respondents about the objectives, rationale, potential benefits and risks of the study was used; informed consent had been given by the ohns when they responded to the questionnaires sent out (Oxford Brooks University 2011; Parahoo 1997). The researchers explained to those participating in the study that they had the right to withdraw from the study at any given time (Burns \& Grove 2006).The researchers at all times adhered to the rights of privacy, respect, confidentiality and anonymity of respondents, by not requiring the names or SASOHN membership numbers of the respondents. In addition to being published in a journal, the findings of this study were communicated to the respondents at monthly sasohn meetings (Parahoo 1997; Polit \& Beck 2004).

\section{Rights of the institutions at which the research was conducted}

The professional body sasohn represents the sanc in governing the scope of practice of ohns. The researchers obtained written permission from the president of sasohn to conduct the study and select the respondents.

\section{Scientific honesty}

The researchers were responsible for submitting to the faculty ethics committee of the university of johannesburg (ethical clearance obtained: aec52/01-2010 and hdc50/022010), as it exists to examine the ethical implications of the

TABLE 3: Factor analysis of items.

\begin{tabular}{|c|c|c|}
\hline Number & Question & Concept \\
\hline Q 3 & Discrimination in terms of your profession. Other professionals believe that you are not capable of conducting an HRA? & Ignorance of the Role of the $\mathrm{OHN}$ \\
\hline Q 1 & Personality conflict with the occupational health medical practitioner? & \\
\hline Q 13 & Conflict with your manager? & \\
\hline Q 5 & Lack of clarity about tasks and goals as an occupational health nursing practitioner? & \\
\hline Q 20 & My input is not valued as an occupational health nursing practitioner? & \\
\hline Q 6 & Lack of reward. I feel that I do not get sufficient reward for what I accomplish in a day? & \\
\hline Q 7 & Possibility of future unemployment. The company is not currently doing well financially? & \\
\hline Q 8 & Personal problems? & \\
\hline Q 11 & Lack of experience in conducting an HRA? & Competency \\
\hline Q 10 & Lack of knowledge in conducting an HRA? & \\
\hline Q9 & Lack of skill in conducting an HRA? & \\
\hline Q 12 & Lack of confidence in conducting an HRA? & \\
\hline Q 19 & I was not trained in conducting an HRA? & \\
\hline Q 14 & Time management. I have too many tasks to do in the day? & Workload \\
\hline Q 2 & Daily workload. I do not have enough time to conduct an HRA? & \\
\hline Q 4 & Leadership and/or management responsibilities are taking too much time in a day? & \\
\hline Q15 & Responsible for too many workers? & \\
\hline Q 18 & I am not interested in conducting an HRA? & Attitude \\
\hline Q 17 & I do not feel it is necessary to conduct an HRA? & \\
\hline Q 16 & I fail to prioritise all my tasks as an occupational health nursing practitioner? & \\
\hline
\end{tabular}

HRA, health risk assessment; OHN, occupational health nurses. 
study and grant permission for the researchers to conduct the study. The researchers ensured theirown competency, accuracy and honesty in the course of the study. The findings will be published in a journal.

\section{Reliability and validity}

According to Mouton (1996), Talbot (1995) and Golafshani (2003), validity can be described as the degree to which an instrument measures the concept it was intended to measure. Reliability describes the consistency of measures obtained in the use of an instrument, and is an indication of the extent of random error in the measurement method. Reliability and validity in this study were ensured in the following ways.

\section{Theoretical validity}

By conducting a thorough literature review, the researchers theoretically identified and defined concepts and definitions in this study. The questionnaire was developed around the defined concepts discussed in the research project to ensure a fit between the conceptual and operational definitions (Burns \& Grove 2006).

\section{Internal validity}

To ensure internal validity, the researchers conducted an in-depth literature review to develop a questionnaire. The researchers used experts in the field of occupational health nursing to improve content validity, and experts in research methodology and statisticians to review the measurement validity of the instrument (Burns \& Grove 2006). By using systematic cluster sampling, the researchers tried to establish validity by ensuring that sample statistics resembled population parameters. A pilot study was conducted to test the relevance and consistency of the questionnaire.

\section{Reliability}

The standard of consistency of the research findings ensured reliability as the instrument was developed by the researchers, overseen by subject experts and tested with a pilot study (Burns \& Grove 2006). Measurements are reliable if the individual responses to the items indicate the same understanding of items and ratings.

\section{Discussion}

The researchers found that the $\mathrm{OHN}$ is a mature, experienced, predominately female practitioner who operates on behalf of a disproportionately large workforce. According to the Health Resources and Services Administration (2004), ageing OHNs indicate that fewer young OHNs appear to enter occupational health nursing.

Occupational hazards were only partially identified by respondents. For example, hazardous biological agents were not identified as a hazard by most respondents. According to Webber (2009), all health hazards need to be identified in the workplace as a hazard has the potential to cause harm. Not all OHNs are trained to conductan HRA and therefore do they are not aware of all the hazards that workers are exposed to in the workplace.
Only $42.3 \%(n=74)$ of the occupational nursing and medically trained respondents designed policies and procedures on occupational HRAs. It was noted that these policies and procedures were kept by people other than occupational nursing and medically trained personnel and not by the OHNs. The policy or procedure on conducting an HRA is a valuable legal document and should be kept in the occupational health setting to facilitate the conducting of an HRA by the OHN (Hattingh \& Acutt 2003; Kamuzora 2006). If only $42.3 \%$ of the respondents designed a policy or procedure on conducting an HRA, this means that $57.7 \%$ of the respondents did not know what the scope, responsibility or framework of conducting an HRA is.

Although time which was spent on conducting HRAs, these assessments were not conducted frequently $(32.5 \%, n=50)$. If OHNs do not conduct HRAs, they are not legally compliant (Mothiba 2010).

The HRA was kept with the OHN (51.4\%; $n=95)$, but also with non-occupational nursing or medically trained personnel $(48.6 \%, n=90)$. Badenhorst (2004) emphasises that it is vitally important that evidence of the HRA be kept by the OHNs as they must study the information obtained and require a sound understanding of the adverse effects associated with specific health hazards to which workers may be exposed. OHNs should develop a medical surveillance programme based on this information in order to be legally compliant. It is important to note that $48.6 \%(n=90)$ of the respondents said staff other than occupational nursing or medically trained staff kept the HRA with them, and there was no input into medical surveillance.

Although less than half of the respondents conducted an HRA as a basis for their medical surveillance programme, more than half conducted medical examinations after conducting an HRA. The conclusion made by the researchers is that more than half of the respondents conducted medical surveillance without knowing what their hazards were in their workplace.

It was found that not only occupational health nursing and medically trained staff interpreted the findings of the HRA. Rogers (2003) states that OHNsare the experts in their occupational health nursing field and should know what the adverse effects of hazards in the workplace are. Untrained staff cannot decide what medical surveillance needs to be conducted on the workers in the workplace.

Four factors influencing the extent to which OHNs conduct HRAs were identified, namely competence, ignorance of the role of the OHN, workload and attitude.

According to SASOHN (2011), the highest possible standards are promoted in occupational health nursing to encourage accreditation and upgrading of professional qualifications. The International Code of Ethics for Occupational Health Professionals adopted by ICOH (2002) states that OHNs shouldcontinuously strive to be familiar with the working environment as well as to develop their competence and to remain well informed in scientific and technical knowledge. This study showed that OHNs are only partially competent in conducting an HRA. 
Ignorance of the role of the OHN was the second reason identified for not conducting an HRA. This is why the role of the OHN needs to be re-examined and redefined. OHNs are the single largest group of healthcare professionals involved in rendering healthcare at the workplace. Their role in the workplace has not been expanded to the extent that their managers know what their role is (Rogers 2003).

The workload of OHNs was also providedas a reason for not conducting an HRA. According to McVicar (2003), the most obvious means of reducing the workload of the OHN is to ensure that staffing levels are adequate to have time to conduct an HRA. OHNs are responsible for a large number of workers and their role is so vast that they do not have the time to conduct an HRA.

The attitude of the OHN was the last reason for not conducting an HRA. According to David (2009), there are three possible targets of change in the OHN: the nurse's knowledge, attitude and behaviour. Conductingan HRA was lacking in the curriculum of the post-basic qualification of the OHNs. This needs to be addressed by the training institutions so that the OHNs have the necessary knowledge and are competent to conduct HRAs. It is necessary to assess the OHNs as total entities, realising that dysfunctional behaviour may often be a function of not only their behaviour or attitude, but also their interactions and the rules and boundaries that control their actions.

\section{Limitations}

The study results cannot be generalised to the entire population, but only to the selected population in the area where this research was conducted.

\section{Recommendations \\ Occupational health nursing practice}

The results of this study highlight the need of the OHN to be assisted in conducting an HRA. Guidelines developed in phase 2 of this study, which is not described in this article, can be used as a guide by the training institutions when the curriculum regarding conducting an HRA is discussed.

\section{Occupational health nursing education}

Based on the findings of the study relating the competence factor of the OHN to conduct an HRA, the assumption can be made that there is scope for adaptation and development in the current curriculum for occupational health nursing at the training institutions. Not only the theory in the curriculum for OHNs needs to be addressed, but a practical exercise needs to be part of the training to assess the OHN student's skill and competence in conducting an HRA.

\section{Occupational health nursing research}

Occupational health nursing research is necessary to support and expand the knowledge base that forms the foundation for occupational health practice. The guidelines assisting the OHNs to conduct HRAs (as discussed in a second article) need to be implemented and further research needs to be conducted after two years to measure any change regarding the OHNs' ability to conduct HRAs.

\section{Conclusion}

HRAs are conducted by OHNs to determine all the occupational health stressors which may affect workers' health.

A quantitative, descriptive design was used in this study. A sampling frame was developed from a list of all SASOHN members in Gauteng and a systematic cluster sampling method was used. A questionnaire was developed and distributed. The researchers ensured validity and reliability and ethical standards were adhered to.

The findings revealed that the $\mathrm{OHN}$ is a mature, experienced, predominately female practitioner who operates on behalf of a disproportionately large number of workers. Four factors influencing these nurses in conducting an HRA to a limited extent were identified, namely competence, ignorance about the role of the $\mathrm{OHN}$, workload and attitude.

In conclusion, the overall objectives of this study have been achieved. OHNs conducted HRAs to a limited extent. Factors hindering them from conducting HRAs were identified by conducting a factor analysis. Guidelines and recommendations were developed to assist the OHNs in conducting HRAs, as will be discussed in a second article.

\section{Acknowledgements Competing interests}

The authors declare that they have no financial or personal relationship(s) which may have inappropriately influenced them in writing this article.

\section{Authors' contributions}

S.B. (University of Johannesburg) acted as project leader, A.G.W.N. (University of Johannesburg) as co-leader and N.d.J. (University of Johannesburg) as researcher.

\section{References}

Academic Technology Services, UCLA, 2002, Introduction to SAS, viewed 17 August 2010, from http://www.ats.ucla.edu/stat/spss/faq/alpha.html

Alberta OHNs' Association (AOHNA), 2005, Competencies for the OHN, viewed 21 April 2009, from http://www.aohna.ab.ca/members/resources/references/ competencies.pdf

Alstone, M. \& Bowles, W., 2003, Research for social workers - An introduction to methods, 2nd edn, Routledge, New York.

Badenhorst, C.J., 2004, 'Occupational health risk assessment: Central to the management of occupational health', International Platinum Conference 'Platinum Adding Value', pp. 47-48, South African Institute of Mining and Metallurgy, Johannesburg.

Burgel, B., Camp, J. \& Lepping, G., 2005, Scientific Committee on Occupational Health Nursing - The nurse's contribution to health of the worker, viewed 25 August 2010, from http://www.icohweb.org/pdf/sconnursing.pdf

Burns, N. \& Grove, S.K., 2006, The practice of nursing research: Conduct, critique and utilization, 6th edn, Elsevier, St Louis.

Camp, J. \& Tanberg, S., 1985, 'Assessment of the worksite: A guide for the occupational and environmental health nurse', AAOHN Update Series 2(4), 2-7.

Cormack, D.F.S., 1996, The research process in nursing, 3rd edn, Blackwell, Oxford.

Carnevale, F., Mendini, M. \& Moriani, G., 2009, Bernardino Ramazzini - Works, Verona.

David, D., 2009, Attitude of a nurse that will help in successful nursing practice, viewed 03 May 2011, from http://www.saching.com/Article/Attitude-of-a-nurse-that-willhelp-in-successful-nursing-practice-/4360 
Department of Labour of South Africa, 1993a, Hazardous Biological Agents Regulations - GNR1390 of 27 December 2001, viewed 22 May 2009, from http://
www.labour.gov.za/DOL/legislation/regulations/occupational-health-and-safety/ www.labour.gov.za/DOL/legislation/regulation
regulation-ohs-hazardous-biological-agents

Department of Labour of South Africa, 1993b, Hazardous Chemical Substances Regulations - GNR1179 of 25 August 1995, viewed 22 May 2009, from http:// www.labour.gov.za/DOL/legislation/regulations/occupational-health-and-safety/ regulation-ohs-hazardous-chemical-substances

Department of Labour of South Africa, 1993c, Occupational Health and Safety Act 85 of 1993 and Regulations, viewed 22 May 2009, from http://www.labour. gov/DOL/downloads/legislation/acts/occupational-health-and-safety-act-andamendments.

Department of Labour of South Africa, 2003, National Occupational Health and Safety Policy, viewed 25 August 2010, from http://www.kznhealth.gov.za/occhealth/ policy2.pdf

Dikeledi, O. \& Singh, T.S., 2010, 'Health effects associated with exposure to hazardous biological agents and their constituents in poultry farming', Occupational Health Southern Africa 16(3), 8-16.

Field, A., 2006, Reliability analysis, viewed 28 November 2010, from http://www. statisticshell.com/reliabilit.pdf

Golafshani, N., 2003, Understanding reliability and validity in quantitative research viewed 15 April 2011, from http://www.nova.edu/sss/QR/OR8-4/golafshani.pdf

Guild, R., Ehrlich, R.I., Johnston, J.R. \& Ross, M.H., 2001, SIMRAC: Handbook of occupational health practice in the South African mining industry, Creda Communications, Johannesburg.

Hattingh, S. \& Acutt, J., 2003, Occupational health: Management \&practice for health practitioners, 3rd edn, Juta, Lansdowne.

Health Resources and Services Administration, 2004, The registered nurse population: Findings from the 2004 national sample - Chapter III: The registered nurse population, viewed 25 April 2011, from http://www.bhpr.hrsa.gov/ healthworkforce/rnsurveys/rnsurvey2004.pdf

International Commission on Occupational Health (ICOH), 2002, International code of ethics for occupational health professionals, viewed 25 August 2010, from http:// icohweb.org/core_docs/code_ethics_eng.pdf

International Council on Mining and Metals (ICMM), 2009, Good practice guidance on occupational HRA, ICMM, London.

International Society of Addiction Journal Editors (ISAJE), 2001, Ethical practice guidelines in addiction publishing: A model for authors, journal editors and other partners, viewed 15 April 2011, from http://www.parint.org/isajewebsite/ other partners, viewed $15 \mathrm{Apr}$
isajebook/appendix-b-web.pdf

Kamuzora, P., 2006, 'Non-decision making in occupational health policies in developing countries', International Journal of Occupational and Environmental Health 12(1), 65-70. http://dx.doi.org/10.1179/oeh.2006.12.1.65

Kritzinger, D., 2009, 'Rand Mutual Assurance - The workmen's compensation carrier for the mining industry', Occupational Health Southern Africa 15(5), 4-5.

Markusic, M., 2009, Simplifying the Likert scale, viewed 15 April 2011, from http:// www.brigthub.com/education/special/articles/13507.aspx
McVicar, A., 2003, 'Workplace stress in nursing: A literature review', Journal of Advanced Nursing 44(6), 633-636, viewed 25 April 2011, from http://www. researchgate.net/publication/0309-240.2003.02883.x.pdf

Mothiba, G., 2010, Safety at workplaces paramount - Mdladlana, viewed 19 April 2011, from http://www.labour.gov.za/DOL/media-desk/media-statements/2010/ safety-at-workplaces-paramount-2013-mdladlana

Mouton, J., 1996, Understanding social research, Van Schaik, Pretoria.

Occupational Health and Safety Management Systems, 2005, OHSAS 18001, viewed 10 February 2011, from http://www.asse.org/publications/standards

O'Neil, S., 2009, Basic statistics for the utterly confused, paper presented at the Faculty of Economic \& Management Sciences, University of Pretoria, 10-15 September, Pretoria.

Ontario Health Promotion E-Bulletin, 2008, Occupational Health Nurse (Medical Surveillance Program), Health, Safety and Environment, UBC Health Clinic, viewed 15 April 2011, from http://www.ohpe.ca/node/9389

Oxford Dictionaries, 2013, 'Extent', viewed 17 July 2013, from http://www. oxforddictionaries.com/definition/english/extent

Oxford Brooks University, 2011, Guidelines for informed consent, viewed 15 Apri 2011, from http://brooks.ac.uk/res/ethics/consent

Pallant, J., 2007, SPSS Survival Manual, 3rd edn, McGraw Hill Open University Press, New York.

Parahoo, K., 1997, Nursing research - Principles, process and issues, Palgrave Macmillan, London.

Polit, D.F. \& Beck, C.T., 2004, Nursing research - Principles, process and methods, 7th edn, Lippincott, Williams \& Wilkens, Philadelphia.

Rogers, B., 2003, Occupational and environmental health nursing: Concepts and practice, 2nd edn, Saunders, Philadelphia.

Singh, T.S., 2010, 'Biological agents causing occupational airborne contact dermatitis', Occupational Health Southern Africa 16(5), 3-32.

South African Society of Occupational Health Nursing Practitioners (SASOHN), 2011, Overview, viewed 23 April 2011, from http://www.sasohn.co.za/A_Overview.asp

Talbot, L.A., 1995, Principles and practice of nursing research, Mosby, St Louis.

University of Queensland, 2010, Occupational health \& safety risk assessment and management guideline, viewed 01 March 2011, from http://www.uq.edu.au/ohs/ pdfs/ohsriskmgt.pdf

University of Waterloo, 2007, OHN - General accountability, viewed 08 February 2011, from http://hr.uwaterloo.ca/jd/00001550.html

Waldon, H.A., 1989, Occupational health practice, 3rd edn, Butterworths, London.

Webber, J., 2009, Hazards and risks in the workplace, viewed 15 March 2011, from http://jessicawebber.hubpages.com/hub/Hazards-and-Risks-in-the-Workplace

Weiers, R.M., 2008, Introduction to business statistics, 6th edn, Thomson, Toronto.

Zungu, L.I., 2007, 'An evaluation of the occupational health programmes of the on-site clinic at a newspaper production industry in South Africa', Occupational Health Southern Africa 13(6), 14-19. 